\title{
TINGKAT PARTISIPASI PETANI DALAM PENGELOLAAN IRIGASI PADA DAERAH IRIGASI NARONGTONG KECAMATAN JATINANGOR
}

\author{
Irfan Ardiansah $^{1 *}$, Selly Harnesa Putri ${ }^{1}$, Nurpilihan Bafdal ${ }^{1}$, Elisa Dian Astriani ${ }^{1}$ \\ ${ }^{1}$ Universitas Padjadjaran, Indonesia \\ *e-Mail: irfan@unpad.ac.id
}

\begin{abstract}
Abstrak
Daerah Irigasi merupakan bagian penting dalam proses pertanian dan telah ditetapkan oleh pemerintah melalui peraturan pengelolaan irigasi partisipatif dan pelaksanaannya melibatkan peran serta masyarakat, masalahnya di Daerah Irigasi Narongtong masyarakat petaninya belum semua berpartisipasi dalam pengelolaannya yang berakibat kurang terawatnya daerah irigasi ini. Penelitian dilakukan untuk mengetahui bagaimana partisipasi petani terhadap pengelolaan Daerah Irigasi Narongtong Kecamatan Jatinangor Kabupaten Sumedang. yang meliputi dua desa, yaitu Desa Cileles dan Desa Cilayung. Penelitian dilakukan dengan metode survey dengan menyebarkan kuesioner tertutup yang dibagikan pada para petani kemudian diolah menggunakan metode analisis deskriptif untuk mendapatkan gambaran tingkat partisipasi petani dalam pengelolaan daerah irigasi Narongtong. Berdasarkan hasil penelitian didapatkan bahwa umumnya petani di kedua Desa ini tidak terlalu peduli untuk mengelola dan merawat DI Narongtong, dan lebih terfokus mengenai bagaimana sawah mereka dapat terairi air irigasi sehingga belum terjadi pemerataan terhadap penggunaan air irigasi. Hal ini dapat terjadi karena umumnya petani pada dua desa tersebut memiliki pendidikan tertinggi Sekolah Dasar (SD) yang menyebabkan pengetahuan mereka menngenai pentingnya pengelolaan Daerah Irigasi menjadi terbatas. Hasil penelitian menunjukkan bahwa petani di Daerah Irigasi Narongtong menganggap bahwa lokasi tersebut adalah milik pemerintah sehingga pengelolaannya harus dilakukan pemerintah. Untuk mengubah persepsi tersebut pemerintah Kabupaten Sumedang bertanggung jawab memberikan informasi yang benar mengenai pengelolaan daerah irigasi dan mengaktifkan Kembali P3A sebagai langkah untuk mengubah persepsi para petani.
\end{abstract}

Kata kunci: Partisipasi Petani; Irigasi Partisipatif; Analytical Hierarchy Process

\begin{abstract}
The irrigation area is an integral part of the agricultural process and has been determined by implementing participatory irrigation management regulations. The implementation involves community participation; the problem is that in the Narongtong Irrigation Area, the farming community has not all participated in its management, resulting in the poor maintenance of this irrigation area. The research was conducted to find out how the participation of farmers in the management of the Narongtong Irrigation Area, Jatinangor District, Sumedang Regency, which includes two villages, namely Cileles Village and Cilayung Village. The research was conducted using a survey method by distributing closed questionnaires distributed to farmers and then processed using descriptive analysis methods to get an idea of the level of farmer participation in the management of the Narongtong irrigation area. Based on the study results, farmers in these two villages did not care about managing and caring for DI Narongtong. They were more focused on how their fields could be irrigated with irrigation water so that there was no equal distribution of irrigation water use. This can happen because generally, the farmers in the two villages have the highest education of Elementary School (SD), which causes their knowledge about the importance of Irrigation Area management to be limited. The results showed that farmers in the Narongtong Irrigation Area considered that the location belonged to the government, so that the management had to be carried out by the government. To change this perception, the government of Sumedang Regency is responsible for providing correct information regarding irrigation area management and re-activating P3A as a step to change farmers' perceptions.
\end{abstract}

Keywords: Farmer Participation; Participative Irrigation; Analytical Hierarchy Process

This is an open access article under the CC BY-SA license.

Copyright (C) 2021 by Author. Published by Universitas Pendidikan Ganesha.

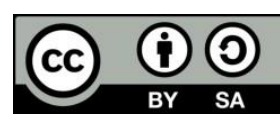




\section{PENDAHULUAN}

Air merupakan komponen yang sangat penting bagi kehidupan. Kebutuhan air untuk berbagai kepentingan semakin lama semakin meningkat, begitu juga pada sektor pertanian. Tingkat kebutuhan air irigasi menjadi semakin kompetitif karena ketersediaan sumber daya air yang terbatas. Hal ini menyebabkan dampak negatif bagi para petani pengguna air (Gines et al., 2018; Ramadhan et al., 2019).

Petani pemakai air adalah seluruh petani yang memperoleh manfaat secara langsung dari pengelolaan air dan jaringan irigasi, termasuk irigasi dengan pompa yang meliputi petani pemilik sawah, petani penggarap sawah, petani penyakap sawah, pemilik kolam ikan yang mendapat air irigasi, dan badan usaha di bidang pertanian yang memanfaatkan air irigasi. Perkumpulan Petani Pemakai Air (P3A) memiliki hak dan tanggung jawab dalam pengembangan dan pengelolaan sistem irigasi tersier (Ardiansah et al., 2018).

Partisipasi petani sebagai
anggota P3A diperlukan dalam kegiatan pengelolaan irigasi yaitu untuk meningkatkan rasa memiliki, rasa tanggung jawab dan kemampuan P3A dalam rangka meningkatkan efisiensi, efektivitas, dan keberlanjutan sistem irigasi (Susilowati, 2019; Wahyuni, 2015). Berdasarkan survei pendahuluan yang dilakukan di Daerah Irigasi Narongtong, Kecamatan Jatinangor, Kabupaten Sumedang, diketahui bahwa belum semua petani berpartisipasi dalam pengelolaan irigasi, sehingga pemanfaatan air irigasi belum dilakukan secara adil dan merata.

Oleh karena itu dilakukan penelitian mengenai analisis tingkat partisipasi petani dalam pengelolaan air irigasi di Daerah Irigasi Narongtong, Kecamatan Jatinangor, Kabupaten Sumedang. Dalam penelitian ini, untuk mengetahui kriteria tingkat partisipasi petani dalam pengelolaan air irigasi dilakukan analisis dengan metode analisis deskriptif yang diperoleh berdasarkan hasil wawancara dan hasil pembagian kuesioner yang ditujukan kepada petani. Selain itu dalam penelitian ini juga dilakukan pengurutan prioritas partisipasi petani dalam pengelolaan air irigasi sehingga diharapkan dapat diperoleh solusi yang tepat dalam pengelolaan air irigasi untuk mewujudkan pemanfaatan air irigasi secara adil dan merata.

Berdasarkan latar belakang maka masalah yang muncul dalam penelitian ini adalah belum terwujudnya pemanfaatan air irigasi secara adil dan merata yang dipengaruhi oleh partisipasi petani dalam pengelolaan air irigasi, sehingga memunculkan pertanyaan seberapa besar tingkat partisipasi petani dalam pengelolaan air irigasi, maka penelitian ini dilakukan untuk mengetahui tingkat partisipasi petani dalam pengelolaan air irigasi di Daerah Irigasi Narongtong.

\section{METODE}

Penelitian ini dilaksanakan di Daerah Irigasi Narongtong yang meliputi Desa Cileles dan Desa Cilayung, Kecamatan Jatinangor, Jurnal IImu Sosial dan Humaniora | 530 
Kabupaten Sumedang, Provinsi Jawa Barat dengan peta lokasi dapat dilihat pada Gambar 1. Waktu yang dibutuhkan dalam penelitian adalah selama 6 (enam) bulan.

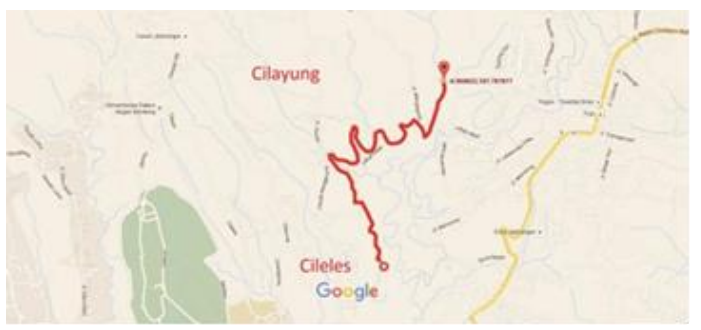

Gambar 1. Lokasi Daerah Irigasi Narongtong

Penelitian ini menggunakan
metode survei yang kemudian dilanjutkan menjadi metode analisis deskripif (Zhang et al., 2017). Survei pada penelitian ini yaitu dengan melakukan wawancara serta penyebaran kuesioner kepada petani. Penyebaran kuesioner kepada petani dilakukan untuk mengetahui tingkat partisipasi petani dalam pengelolaan air irigasi.

Survei lapangan bertujuan untuk mengetahui kondisi umum dari Daerah Irigasi Narongtong beserta dua desa yang daerah sawahnya dialiri oleh daerah irigasi tesebut yaitu Desa Cileles dan Desa Cilayung, sedangkan wawancara dilakukan kepada ketua atau anggota P3A guna memperoleh informasi mengenai partisipasi petani dalam pengelolaan air irigasi.

\section{Pengambilan Sampel Penelitian}

Populasi adalah keseluruhan bagian atau anggota dari objek yang akan diteliti atau diamati (Supranto, 2000). Berdasarkan data dari Kantor
Kecamatan Jatinangor, jumlah populasi masyarakat petani Desa Cilayung adalah sejumlah 600 orang dan masyarakat petani Desa Cileles adalah sejumlah 162 orang.

Sampel adalah sebagian dari populasi yang memiliki karakteristik yang sama dengan populasi. Teknik pengambilan sampel pada penelitian ini menggunakan teknik simple random sampling, yaitu pengambilan sampel dari populasi dilakukan secara acak tanpa memperhatikan strata yang ada dalam populasi tersebut, sehingga teknik sampel ini memberikan peluang yang sama bagi setiap anggota populasi untuk dipilih menjadi anggota sampel (Bijani et al., 2017; Diaz et al., 2016).

Cara penarikan sampel dalam penelitian ini mengacu pada argument bahwa pengambilan sampel apabila subjeknya kurang dari 100 , lebih baik diambil semua sehingga penelitiannya merupakan penelitian populasi, tetapi jika jumlah subjeknya besar, dapat diambil antara $10-15 \%$ atau $20-25 \%$ atau lebih, tergantung setidak-tidaknya dari: (1) kemampuan peneliti dilihat dari waktu, tenaga, dan dana, (2) sempit luasnya wilayah pengamatan dari setiap subjek, dan (3) besar kecilnya risiko yang ditanggung oleh peneliti (Supranto, 2000). Pengambilan jumlah sampel dalam penelitian ini dilakukan dengan menggunakan data sebesar $15 \%$ dari jumlah populasi, dengan perhitungan sebagai berikut:

$N=15 \% \times P$

Keterangan:

$\mathrm{N}=$ Jumlah sampel

$\mathrm{P}=$ Jumlah Populasi $15 \%$

Jurnal IImu Sosial dan Humaniora | 531 
Dengan jumlah responden di P3A Saluyu Hulu (Desa Cilayung) dengnan populasi sebanyak 600 orang:

$$
N=15 \% \times 600=90 \text { Responden }
$$

Dengan jumlah responden di P3A Saluyu Hilir (Desa Cileles) dengan populasi sebanyak 162 orang

$$
N=15 \% \times 162=25 \text { Responden }
$$

\section{Perancangan Kuesioner}

Adapun metode yang digunakan dalam penelitian ini adalah menggunakan kuesioner. Metode kuesioner/angket merupakan sejumlah pertanyaan atau pernyataan tertulis yang dibuat dengan tujuan untuk memperoleh informasi dari responden atau hal-hal yang responden ketahui (Krosnick, 2018). Penelitian ini menggunakan kuesioner yang ditujukan kepada petani berupa kuesioner untuk mengetahui tingkat partisipasi petani dalam pengelolaan air irigasi mengetahui prioritas kegiatan pengelolaan air irigasi.

Perancangan kuesioner dilakukan dengan tujuan untuk memperoleh informasi mengenai seberapa besar tingkat partisipasi petani dalam pengelolaan irigasi. Perancangan kuesioner ini dibuat berdasarkan hasil wawancara kepada Ketua Perkumpulan Petani Pemakai Air (P3A) di Daerah Irigasi Narongtong mengenai partisipasi petani dalam pengelolaan irigasi. Responden dalam penelitian ini ditujukan kepada petani di Daerah Irigasi Narongtong, yaitu meliputi Desa Cilayung dan Desa Cileles.

Kuesioner yang dibuat terdiri dari 14 pertanyaan dan berupa pertanyaan tertutup, untuk memperoleh parameter skala pengukuran, maka jawaban responden diklasifikasikan berdasarkan interval. Jawaban yang diberikan responden merupakan jawaban yang berbeda-beda dan berupa data kualitatif, maka jawaban tersebut diklasifikasikan berdasarkan interval dengan parameter penilaian (Anderson et al., 2018).

Agar semua data dapat dianalisis, maka data kualitatif tersebut harus diubah menjadi data kuantatif dengan menggunakan skala Likert yang digunakan untuk mengklasifikasikan variabel yang akan diukur supaya tidak terjadi kesalahan dalam menentukan analisis data dan langkah selanjutnya Skala ini berinterasi 1-5 dengan pilihan jawaban dan pemberian skor untuk masing-masing jawaban dalam kuesioner (Supranto, 2000).

Penyebaran kuesioner kepada petani bertujuan guna memperoleh informasi mengenai tingkat partisipasi dan tingkat motivasi petani berpartisipasi dalam pengelolaan air irigasi. Kuesioner ditujukan kepada petani di Desa Cileles dan Desa Cilayung. Penyebaran kuesioner dilakukan dengan cara membacakan kuesioner kepada petani dengan menggunakan bahasa daerah dan kalimat yang mudah dipahami oleh petani, sehingga petani mampu menjawab setiap pertanyaan dengan benar.

\section{Penelitian Sejenis}

Penelitian mengenai partisipasi petani telah dilakukan pada petani kemiri di Kabupaten Maros Sulawesi Selatan untuk menjaga, mengelola 
keberlanjutan hutan kemiri dan pemanfaatannya melalui penyebaran kuesioner, wawancara, observasi dan studi literatur yang menunjukkan bahwa motivasi petani tergolong sedang tetapi partisipasinya tergolong rendah yang berpengaruh terhadap pengelolaan hutan kemiri (Suprayitno et al., 2015).

Penelitian serupa juga telah dilakukan pada kegiatan pengelolaan jaringan irigasi tersier di Kabupaten Maros, Sulawesi Selatan menggunakan pendekatan kualitatif dan kuantitatif dengan lokasi penelitian di Desa Alatengae dengan kesimpulan bahwa tingkat partisipasi petani di bagian hulu dan tengah masuk dalam kategori sedang, sedangkan pada bagian hilir berada dalam kategori tinggi (Putriani et al., 2018).

Penelitian mengenai pengukuran partisipasi petani dalam kegiatan penyuluhan dan pemupukan adopsi sawah yang dilakukan oleh (Putri et al., 2019) menggunakan sampel penelitian sebanyak 87 orang petani padi sawah menunjukkan bahwa partisipasi petani dalam kegiatan penyuluhan tergolong rendah yang terpengaruh oleh luas lahan dan waktu kegiatan penyuluhan.

Ketiga penelitian yang telah dilakukan ini menunjukkan bahwa umumnya petani memiliki tingkat partisipasi yang cukup rendah dalam pengelolaan lingkungan pertaniannya. $\mathrm{Hal}$ ini terpengaruh oleh tingkat pendidikan dan faktor ekonomi para petani penggarap pada daerah tersebut cukup rendah.

\section{HASIL DAN PEMBAHASAN}

Berdasarkan Dinas Pekerjaan
Umum Bidang Sumber Daya Air

Pemerintah Kabupaten Sumedang, Daerah Irigasi Narongtong memiliki luas sebesar 100 ha dan panjang 3800 m. Daerah Irigasi Narongtong mengairi dua desa, yaitu Desa Cilayung dan Desa Cileles. Daerah Irigasi Narongtong ini bersumber dari Sungai Cikeruh, dengan debit minimal sungai sebesar 0,453 $\mathrm{m}^{3} /$ detik dan debit maksimal sungai sebesar 0,458 $\mathrm{m}^{3} /$ detik. Sistem pengambilan air dilakukan dengan membuat bendung. Tipe bendung tersebut adalah bendung tetap dengan lebar efektif bendung sebesar $8 \mathrm{~m}$ dan kapasitas pengambilan sebesar $0,450 \mathrm{~m}^{3} /$ detik.

Jaringan irigasi yang terdapat di Daerah Irigasi Narongtong ini merupakan jaringan irigasi semi teknis. Luas potensial jaringan irigasinya seluas 370 ha dengan petak tersier sebanyak 20 buah. Pola tanam yang dilakukan di Daerah Irigasi Narongtong ini berupa padi-palawija-palawija, dengan luas tanam ketika musim hujan yaitu seluas 370 ha dan ketika musim kemarau seluas 368 ha. Kebutuhan air irigasi di intake yaitu sebanyak 444 liter/detik/ha dengan debit maksimum di intake sebesar 0,450 $\mathrm{m}^{3} /$ detik.

Berdasarkan hasil penelitian, diperoleh tanggapan kuesioner dari 115 responden untuk menentukan tingkat partisipasi petani dalam pengelolaan air irigasi sebagai berikut.

\section{Penyuluhan/Pembinaan dari P3A}

Gambar 2 menunjukkan bahwa responden memberikan tanggapan terbanyak pada jawaban jarang dengan jumlah responden sebanyak 30 orang dan responden memberikan tanggapan paling sedikit pada jawaban sering 
dengan jumlah responden sebanyak 13 orang. Berdasarkan hasil wawancara, diperoleh informasi bahwa petani di DI Narongtong sebagian besar jarang menghadiri kegiatan penyuluhan/pembinaan dari P3A karena beberapa alasan, diantaranya yaitu: (1) kurang aktifnya P3A di DI Narongtong sehingga kegiatan penyuluhan/ pembinaan dari P3A tidak diselenggarakan secara berkala, dan (2) kurangnya informasi mengenai kegiatan penyuluhan/ pembinaan dari P3A sehingga ada beberapa petani yang tidak mengetahui adanya kegiatan tersebut.

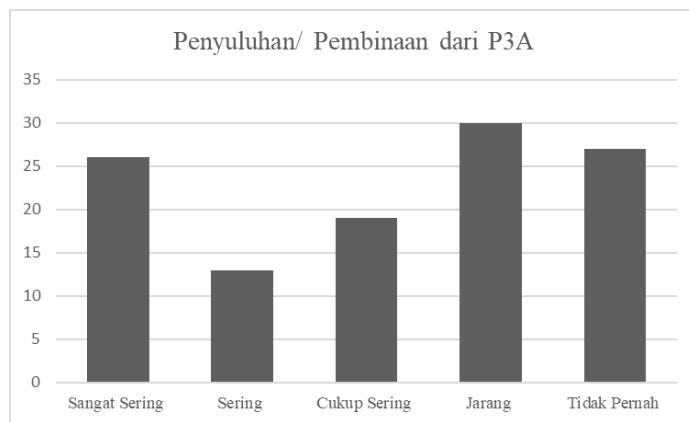

Gambar 2. Tanggapan Responden terhadap Penyuluhan/ Pembinaan dari P3A

Menanggapi hal tersebut, maka P3A harus diaktifkan kembali agar kegiatan penyuluhan/ pembinaan dari P3A dapat diselenggarakan secara berkala dengan informasi yang jelas, sehingga dengan begitu kegiatan pengelolaan irigasi dapat berjalan dengan benar secara adil dan merata. Selain itu, petani DI Narongtong harus dihimbau untuk mengikuti kegiatan penyuluhan/ pembinaan dari P3A agar dapat menanamkan pemahaman bahwa betapa pentingnya peran/partisipasi petani dalam pengelolaan air irigasi.

\section{Penjadwalan Pembagian Air Irigasi}

Gambar 3 menunjukkan bahwa responden memberikan tanggapan terbanyak pada jawaban sering dengan jumlah responden sebanyak 47 orang dan responden memberikan tanggapan paling sedikit pada jawaban cukup sering dengan jumlah responden sebanyak 3 orang. Berdasarkan hasil wawancara, diperoleh informasi bahwa petani di DI Narongtong sebagian besar sering menjadwalkan atau melakukan pembagian air irigasi karena pada saat musim kemarau mereka selalu kesulitan memperoleh air irigasi karena air sungai surut dan aliran air irigasi menjadi lebih sedikit, sehingga mereka perlu melakukan pembagian air secara bergilir demi keberlangsungan hidup tanaman.

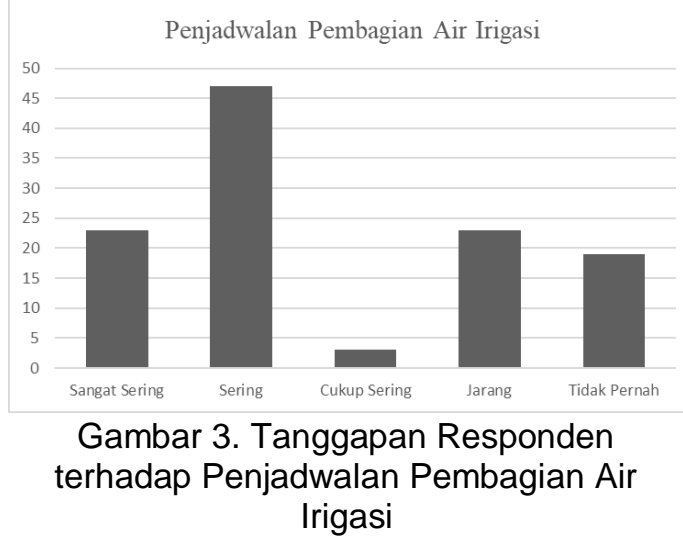

Menanggapi hal tersebut, maka diperlukan pembagian air yang adil dan merata yaitu dengan jumlah waktu pembagian air yang terjadwal, sehingga dengan begitu air mampu didistribusikan dari hulu hingga ke area

Jurnal IImu Sosial dan Humaniora | 534 
persawahan yang terletak di hilir. Kelancaran mengalirnya air irigasi tidak hanya dipengaruhi oleh jumlah air sungai, namun kebersihan saluran dari sampah, sedimen, dan tanaman liar juga perlu diperhatikan karena dapat mempengaruhi debit air sungai.

\section{Penjadwalan Tata Tanam}

Gambar 4 menunjukkan bahwa responden memberikan tanggapan terbanyak pada jawaban sangat sering dan sering dengan jumlah responden sebanyak 38 orang dan responden memberikan tanggapan paling sedikit pada jawaban jarang dengan jumlah responden sebanyak 7 orang. Berdasarkan hasil wawancara, diperoleh informasi bahwa petani di DI Narongtong sebagian besar sangat sering menjadwalkan tata tanam, karena mereka menyesuaikan antara tanaman yang akan ditanam dengan jumlah kebutuhan air irigasi. Ketika musim hujan, mereka menanam padi karena padi membutuhkan air irigasi yang agak banyak, sedangkan pada musim kemarau dimana ketersediaan air irigasi berkurang, mereka lebih memilih menanam tanaman palawija karena tidak membutuhkan air irigasi yang banyak.

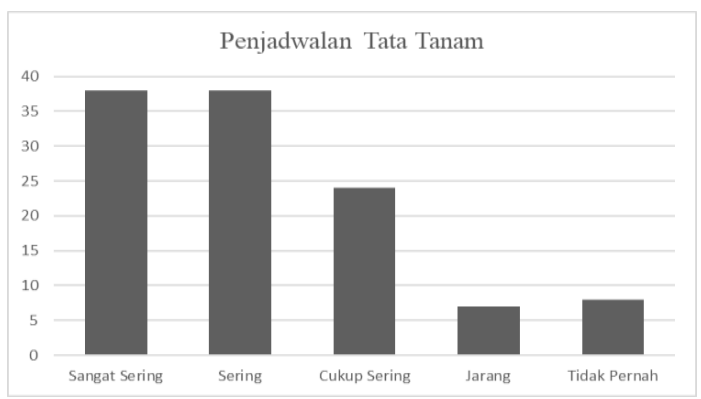

Gambar 4. Tanggapan Responden terhadap Penjadwalan Tata Tanam
Menanggapi hal tersebut, penjadwalan pola tata tanam harus dilakukan secara serempak dan disesuaikan dengan kebutuhan air irigasi, sehingga proses penanaman di daerah hulu maupun hilir dapat berjalan dengan baik dan menghindari terjadinya gagal panen yang dapat merugikan petani.

\section{luran Dana dan Material}

Gambar 5 menunjukkan bahwa responden memberikan tanggapan terbanyak pada jawaban jarang dengan jumlah responden sebanyak 38 orang dan responden memberikan tanggapan paling sedikit pada jawaban tidak pernah dan cukup sering dengan jumlah responden sebanyak 9 orang. Berdasarkan hasil wawancara, diperoleh informasi bahwa petani di DI Narongtong sebagian besar jarang memberikan iuran dana atau material karena dipengaruhi oleh faktor ekonomi, seperti banyaknya jumlah tanggungan keluarga yang masih harus dipenuhi kebutuhannya, serta status pekerjaan lain selain bekerja menjadi petani. Beberapa alasan tersebut mengakibatkan sebagian besar petani kesulitan berpartisipasi dalam memberikan iuran dana dan material.

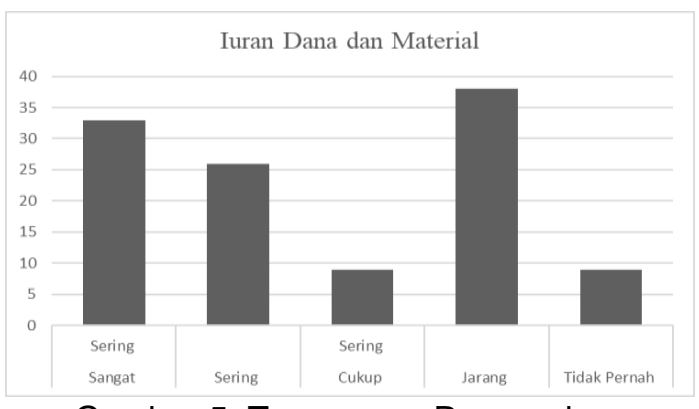

Gambar 5. Tanggapan Responden terhadap luran Dana dan Material

Jurnal IImu Sosial dan Humaniora | 535 


\section{Mencabut Rumput/Tanaman Liar di Sekitar Saluran}

Gambar 6 menunjukkan bahwa responden memberikan tanggapan terbanyak pada jawaban sering dengan jumlah responden sebanyak 79 orang dan responden memberikan tanggapan paling sedikit pada jawaban tidak pernah dan jarang dengan jumlah responden sebanyak 4 orang. Berdasarkan hasil wawancara, diperoleh informasi bahwa petani di DI Narongtong sebagian besar sering mencabut rumput/tanaman liar di sekitar saluran karena mereka menyadari bahwa jika saluran irigasi dipenuhi oleh rumput/tanaman liar maka akan menyebabkan irigasi menjadi tersumbat dan debit aliran menjadi kecil sehingga distribusi air irigasi menjadi terhambat. Menanggapi hal tersebut, sebaiknya mencabut rumput/tanaman liar di sekitar saluran harus dilakukan secara rutin yaitu di daerah hulu hingga hilir agar air irigasi dapat mengalir dengan lancar hingga ke seluruh daerah persawahan.

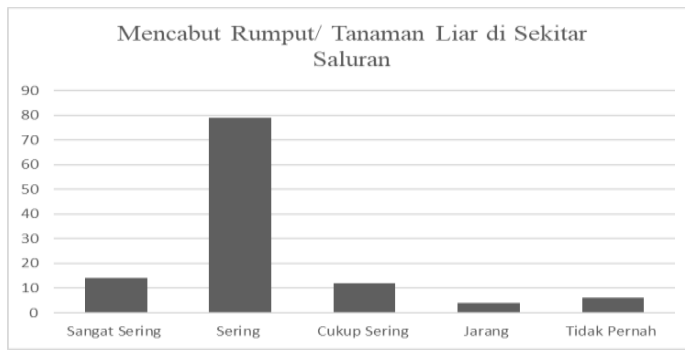

Gambar 6. Tanggapan Responden terhadap Mencabut Rumput/Tanaman Liar di Sekitar Saluran

\section{Mengangkat Lumpur/Sedimen di Saluran Irigasi}

Gambar 7 menunjukkan bahwa responden memberikan tanggapan terbanyak pada jawaban tidak pernah dengan jumlah responden sebanyak 32 orang, hal ini berbeda sedikit dengan jumlah responden yang memberikan tanggapan sangat sering yaitu sebanyak 30 orang, kemudian responden yang memberikan tanggapan paling sedikit yaitu pada jawaban sering dengan jumlah responden sebanyak 12 orang. Berdasarkan hasil wawancara, diperoleh informasi bahwa petani di DI Narongtong sebagian besar tidak pernah dan sebagian besar lagi sering mengangkat lumpur/sedimen dari saluran. Hal ini disebabkan oleh lokasi sawah petani tersebut. Petani yang sangat sering megangkat lumpur/sedimen di saluran irigasi sebagian besar berada di daerah hulu atau dekat dengan sumber air, sedangkan petani yang tidak pernah mengangkat lumpur/sedimen di saluran irigasi sebagian besar berada di bagian hilir atau jauh dari sumber air.

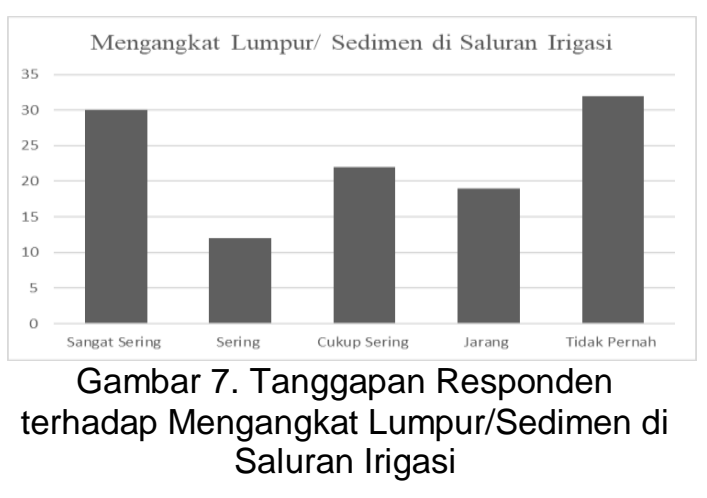

Menanggapi hal tersebut, pengangkatan lumpur/sedimen di saluran irigasi harus dilakukan secara berkala, karena jika di saluran irigasi terdapat lumpur/sedimen maka dapat menyumbat aliran air dan

Jurnal IImu Sosial dan Humaniora | 536 
mempengaruhi debit air, begitu juga di saluran drainase, lumpur/sedimen harus diangkat agar pembuangan kelebihan air berjalan lancar dan tidak menyebabkan banjir.

\section{Membersihkan Saluran dari Sampah}

Gambar 8 menunjukkan bahwa responden memberikan tanggapan terbanyak pada jawaban sangat sering dengan jumlah responden sebanyak 77 orang dan responden memberikan tanggapan paling sedikit pada jawaban jarang dengan jumlah responden sebanyak 2 orang. Berdasarkan hasil wawancara, diperoleh informasi bahwa petani di DI Narongtong sebagian besar sangat sering mencabut rumput/tanaman liar di sekitar saluran karena mereka menyadari bahwa jika saluran irigasi dipenuhi oleh sampah maka akan menyebabkan irigasi menjadi tersumbat dan debit aliran menjadi kecil sehingga distribusi air irigasi menjadi terhambat. Menanggapi hal tersebut, sebaiknya membersihkan saluran dari sampah harus dilakukan secara rutin yaitu di daerah hulu hingga hilir agar air irigasi dapat mengalir dengan lancar hingga ke seluruh daerah persawahan.

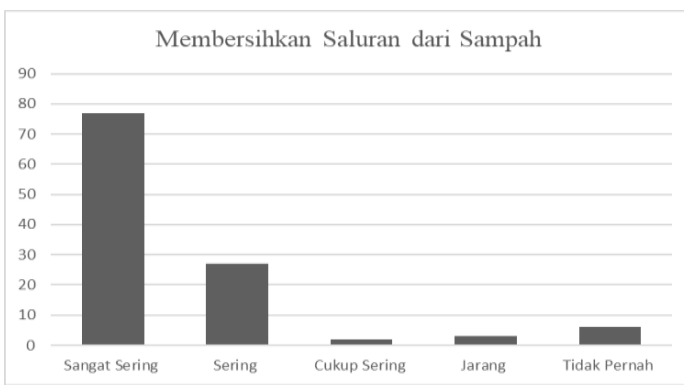

Gambar 8. Tanggapan Responden terhadap Membersihkan Saluran dari Sampah

\section{Pengecekan/Penelusuran Saluran Irigasi}

Gambar 9 menunjukkan bahwa responden memberikan tanggapan terbanyak pada jawaban tidak pernah dengan jumlah responden sebanyak 57 orang dan responden memberikan tanggapan paling sedikit pada jawaban cukup sering dengan jumlah responden sebanyak 4 orang. Berdasarkan hasil wawancara, diperoleh informasi bahwa petani di DI Narongtong sebagian besar tidak pernah melakukan pengecekan atau penelusuran saluran irigasi karena jarak dari hulu ke hilir merupakan jarak yang jauh sehingga membutuhkan energi untuk menelusuri saluran irigasi. Selain itu, mereka hanya melakukan pengecekan saluran air di sekitar area persawahan masing-masing saja yang menjadi tanggung jawab mereka.

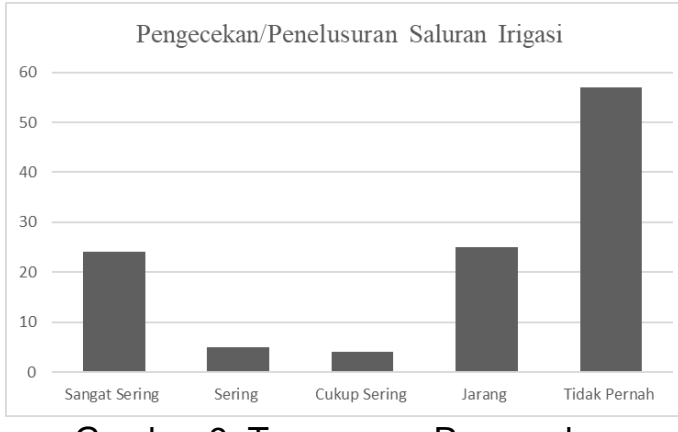

Gambar 9. Tanggapan Responden terhadap Pengecekan/Penelusuran Saluran Irigasi

Menanggapi hal tersebut, pengecekan atau penelusuran saluran perlu dilakukan secara rutin oleh masyarakat petani DI Narongtong agar dapat mengetahui kondisi saluran irigasi dan agar dapat mencegah terjadinya kerusakan saluran, sehingga

Jurnal IImu Sosial dan Humaniora | 537 
saluran irigasi dapat berfungsi dengan baik.

\section{Pemberian Oli/Pelumas pada Pintu Air}

Gambar 10 menunjukkan bahwa responden memberikan tanggapan terbanyak pada jawaban tidak pernah dengan jumlah responden sebanyak 86 orang dan responden memberikan tanggapan paling sedikit pada jawaban sering dengan jumlah responden sebanyak 1 orang. Berdasarkan hasil wawancara, diperoleh informasi bahwa petani di DI Narongtong sebagian besar tidak pernah melakukan pemberian oli/pelumas pada pintu air karena sudah ada P3A sehingga memberikan oli/pelumas merupakan tanggung jawab P3A. Selain itu, karena tidak ada dana untuk membeli oli/ pelumas. Menanggapi hal ini, demi kebutuhan bersama dibutuhkan koordinasi dan kerjasama yang jelas antara P3A dengan masyarakat mengenai pihak yang bertugas memberikan oli/pelumas dan sumber dana pembelian pelumas, sehingga pintu air dapat berfungsi dengan baik dan irigasi dapat berjalan lancar.

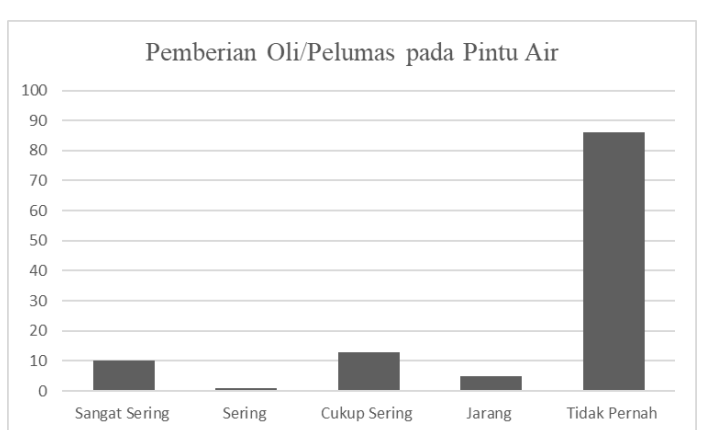

Gambar 10. Tanggapan Responden terhadap Pemberian Oli/Pelumas pada Pintu Air

\section{Mengecat Tembok Saluran}

Berdasarkan grafik pada Gambar 11, yaitu mengenai kegiatan mengecat tembok saluran di DI Narongtong, diketahui bahwa responden memberikan tanggapan terbanyak pada jawaban tidak pernah dengan jumlah responden sebanyak 77 orang dan responden memberikan tanggapan paling sedikit pada jawaban jarang dengan jumlah responden sebanyak 6 orang. Berdasarkan hasil wawancara, diperoleh informasi bahwa petani di DI Narongtong sebagian besar tidak pernah melakukan pengecatan pada tembok saluran karena sudah ada P3A sehingga mengecat tembok saluran merupakan tanggung jawab P3A. Selain itu, karena tidak ada dana untuk membeli cat. Menanggapi hal ini, demi kebutuhan bersama dibutuhkan koordinasi dan kerjasama yang jelas antara P3A dengan masyarakat mengenai kegiatan pengecatan tembok saluran dan sumber dana pembelian cat, sehingga tidak hanya fungsi saluran saja yang dirawat, tetapi keindahan dan kerapihan juga perlu diperhatikan dengan melakukan kegiatan pengecatan tembok saluran yang dilakukan secara berkala.

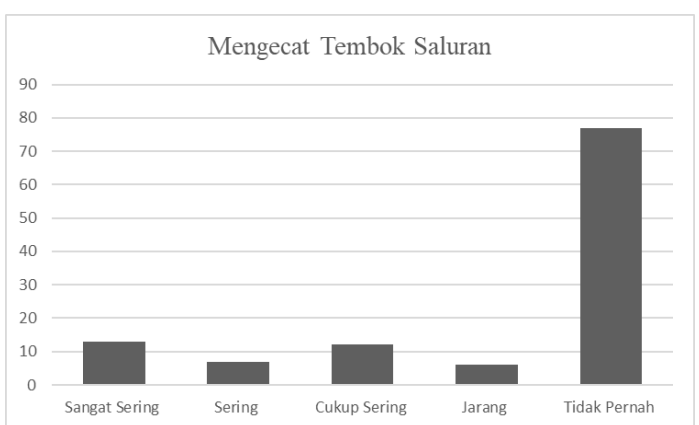

Gambar 11. Tanggapan Responden terhadap Mengecat Tembok Saluran

Jurnal IImu Sosial dan Humaniora | 538 


\section{Mengkalibrasi Pintu Air}

Gambar 12 menunjukkan bahwa responden memberikan tanggapan terbanyak pada jawaban tidak pernah dengan jumlah responden sebanyak 50 orang dan responden memberikan tanggapan paling sedikit pada jawaban cukup sering dengan jumlah responden sebanyak 8 orang. Berdasarkan hasil wawancara, diperoleh informasi bahwa petani di DI Narongtong sebagian besar tidak pernah melakukan kalibrasi pintu air karena sudah ada P3A sehingga mengkalibrasi pintu air merupakan tanggung jawab P3A. Menanggapi hal ini, demi kebutuhan bersama dibutuhkan koordinasi dan kerjasama yang jelas antara P3A dengan masyarakat mengenai kegiatan mengkalibrasi pintu air secara berkala, sehingga pintu air selalu dapat berfungsi dengan baik dan air irigasi dapat disalurkan sesuai dengan kebutuhan.

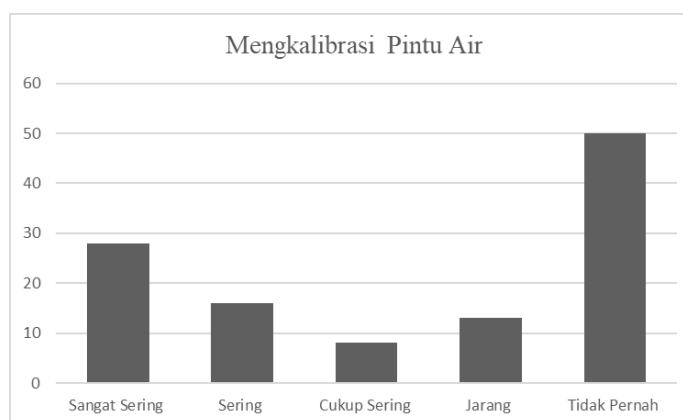

Gambar 12. Tanggapan Responden terhadap Mengkalibrasi Pintu Air

\section{Perbaikan Pintu Air}

Gambar 13 menunjukkan bahwa responden memberikan tanggapan terbanyak pada jawaban tidak pernah dengan jumlah responden sebanyak 49 orang dan responden memberikan tanggapan paling sedikit pada jawaban sering dengan jumlah responden sebanyak 6 orang. Berdasarkan hasil wawancara, diperoleh informasi bahwa petani di DI Narongtong sebagian besar tidak pernah turut serta bekerjasama melakukan perbaikan pintu air karena sudah ada P3A sehingga perbaikan pintu air merupakan tanggung jawab P3A. Menanggapi hal ini, demi kebutuhan bersama dibutuhkan koordinasi dan kerjasama yang jelas antara P3A dengan masyarakat mengenai kegiatan perbaikan pintu air jika terjadi kerusakan, sehingga pintu air selalu dapat berfungsi dengan baik dan air irigasi dapat disalurkan sesuai dengan kebutuhan.

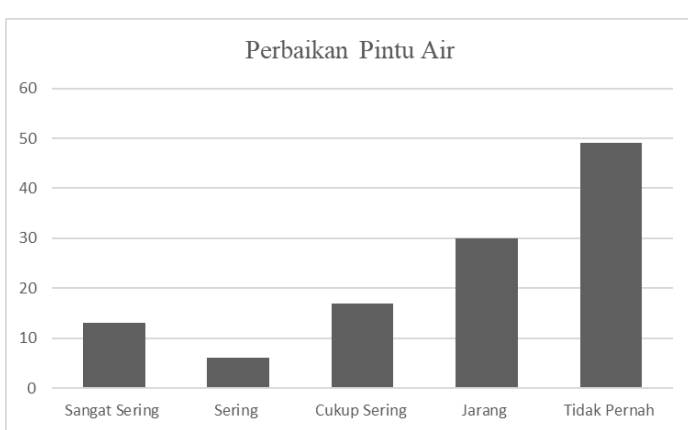

Gambar 13. Tanggapan Responden terhadap Perbaikan Pintu Air

\section{Perbaikan Saluran Irigasi}

Gambar 14 menunjukkan bahwa responden memberikan tanggapan terbanyak pada jawaban tidak pernah dengan jumlah responden sebanyak 39 orang dan responden memberikan tanggapan paling sedikit pada jawaban cukup sering dengan jumlah responden sebanyak 5 orang. Berdasarkan hasil wawancara, diperoleh informasi bahwa petani di DI Narongtong sebagian besar tidak pernah turut serta bekerjasama

Jurnal IImu Sosial dan Humaniora | 539 
melakukan perbaikan saluran air karena sudah ada P3A sehingga perbaikan saluran air irigasi merupakan tanggung jawab P3A. Selai itu, sebagian besar petani beralasan bahwa karena mereka perempuan, maka pekerjaan tersebut dititik beratkan kepada petani laki-laki. Menanggapi hal ini, demi kebutuhan bersama dibutuhkan koordinasi dan kerjasama yang jelas antara P3A dengan masyarakat mengenai kegiatan perbaikan saluran air irigasi jika terjadi kerusakan, sehingga saluran air irigasi selalu dapat berfungsi dengan baik dan air irigasi dapat disalurkan sesuai dengan kebutuhan.

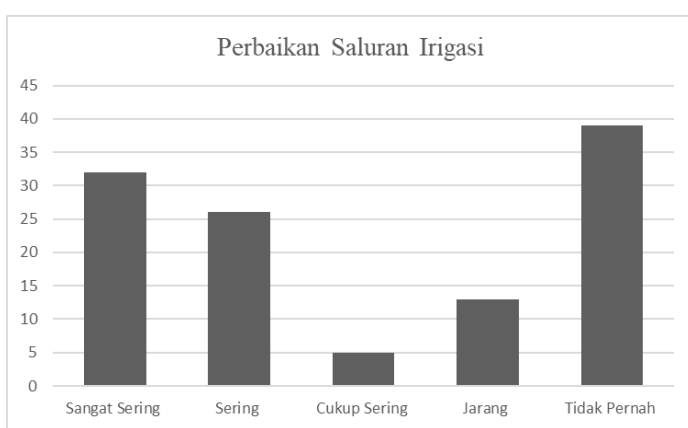

Gambar 14. Tanggapan Responden terhadap Perbaikan Saluran Irigasi

\section{Perbaikan Saluran Drainase}

Gambar 15 menunjukkan bahwa responden memberikan tanggapan terbanyak pada jawaban tidak pernah dengan jumlah responden sebanyak 47 orang dan responden memberikan tanggapan paling sedikit pada jawaban cukup sering dengan jumlah responden sebanyak 8 orang. Berdasarkan hasil wawancara, diperoleh informasi bahwa petani di DI Narongtong sebagian besar tidak pernah turut serta bekerjasama melakukan perbaikan saluran drainase karena sudah ada P3A sehingga perbaikan saluran drainase merupakan tanggung jawab P3A. Selai itu, sebagian besar petani beralasan bahwa karena mereka perempuan, maka pekerjaan tersebut dititik beratkan kepada petani laki-laki. Menanggapi hal ini, demi kebutuhan bersama dibutuhkan koordinasi dan kerjasama yang jelas antara P3A dengan masyarakat mengenai kegiatan perbaikan saluran drainase jika terjadi kerusakan, sehingga kelebihan air dapat disalurkan/dibuang dan tidak menyebabkan banjir.

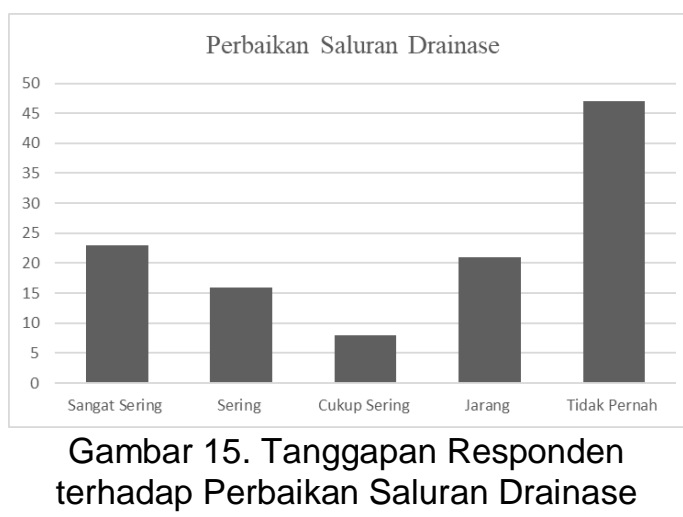

\section{SIMPULAN DAN SARAN}

Adapun simpulan yang dapat diperoleh dari penelitian ini adalah total skor yang diperoleh berdasarkan hasil kuesioner tingkat pasrtisipasi petani dalam pengelolaan air irigasi adalah sebesar 4656. Dengan demikian, berdasarkan kriteria yang ditetapkan, maka tingkat partisipasi petani di DI Narongtong termasuk ke dalam kategori partisipasi rendah. Hal ini menggambarkan bahwa petani di DI Narongtong masih memerlukan penyuluhan dan pendampingan dari pemerintah untuk dapat secara optimal

Jurnal IImu Sosial dan Humaniora | 540 
menngelola daerah irigasi tersebut, hal ini juga terpengaruh dari tingkat pendidikannya yang masih didominasi lulusan Sekolah Dasar (SD). Pengaktifan kembali P3A juga dapat menjadi solusi dengan peran sebagai penyokong dan pengawas sehingga petani merasa memiliki daerah irigasi yang mereka gunakan dan bertanggung jawab untuk mengelolanya.

Peningkatan partisipasi pertani dalam pengelolaan irigasi dapat dilakukan dengan campur tangan pemerintah dalam memberikan materi pengetahuan mengenai pentingnya pengelolaan daerah irigasi dalam meningkatkan kualitas tanaman dan hasil produksi pertanian. Sebagian besar petani di daerah irigasi Narongtong tidak merasa memiliki derah irigasi tersebut karena merasa bahwa lokasi tersebut dibangun oleh pemerintah dan tidak merasa memilikinya, sehingga berasumsi bahwa daerah irigasi tersebut pun harus dikelola oleh pemerintah. Pemerintah Kabupaten Sumedang bertanggung jawab untuk memberikan informasi yang benar mengenai pengelolaan daerah irigasi dan mengaktifkan kembali P3A sebagai langkah untuk mengubah persepsi para petani dalam memandang daerah irigasi Narongtong.

Penelitian selanjutnya diharapkan dapat membangun tingkat prioritas pengelolaan Daerah irigasi Narongtong menggunakan metode sistem pendukung keputusan untuk menentukan urutan prioritas partisipasi petani berdasarkan masukan dari pakar irigasi, sehingga perawatan daerah irigasi dapat terjalin lebih efektif dan efisien.

\section{DAFTAR PUSTAKA}

Anderson, J. A. E., Mak, L., Chahi, A. K., \& Bialystok, E. (2018). The language and social background questionnaire: Assessing degree of bilingualism in a diverse population. Behavior Research Methods, 50(1), 250-263.

Ardiansah, I., Bramadi, R., Wargadibrata, N., Asdak, C., Rahmah, D. M., \& Putri, S. H. (2018). Partisipasi Petani Terhadap Pengelolaan Air Irigasi Di Kecamatan Rancaekek, Kabupaten Bandung, Provinsi Jawa Barat. Jurnal Sains, Teknologi Dan Industri, 16(1), 714.

Bijani, M., Ghazani, E., Valizadeh, N., \& Haghighi, N. F. (2017). Proenvironmental analysis of farmers' concerns and behaviors towards soil conservation in central district of Sari County, Iran. International Soil and Water Conservation Research, 5(1), 43-49.

Diaz, F., Gamon, M., Hofman, J. M., Kiciman, E., \& Rothschild, D. (2016). Online and social media data as an imperfect continuous panel survey. PLoS ONE, 11(1), $1-22$.

https://doi.org/10.1371/journal.pon e.0145406

Gines, G. A., Bea, J. G., \& Palaoag, T. D. (2018). Characterization of Soil Moisture Level for Rice and Maize Crops using GSM Shield and Arduino Microcontroller. IOP Conference Series: Materials 
Science and Engineering, 325, $012019 \quad$ (6 10.$)$. https://doi.org/10.1088/1757899X/325/1/012019

Krosnick, J. A. (2018). Questionnaire design. In The Palgrave handbook of survey research (pp. 439-455). Springer.

Putri, C. A., Anwarudin, O., \& Sulistyowati, D. (2019). Partisipasi Petani Dalam Kegiatan Penyuluhan Dan Adopsi Pemupukan Padi Sawah Di Kecamatan Kersamanah Kabupaten Garut. Jurnal Agribisnis Terpadu, 12(1), 103. https://doi.org/10.33512/jat.v12i1.5 538

Putriani, R., Tenriawaru, A., \& Amrullah, A. (2018). Pengaruh Faktor - Faktor Partisipasi Terhadap Tingkat Partisipasi Petani Anggota P3a Dalam Kegiatan Pengelolaan Saluran Irigasi. Jurnal Sosial Ekonomi Pertanian, 14(3), 263. https://doi.org/10.20956/jsep.v14i3 .5498

Ramadhan, F., Ardiansah, I., \& Kastaman, R. (2019). Perancangan Purwarupa Alat Penyiraman Otomatis pada Tanaman Pisang dengan Internet of Things (IoT). Jurnal Rekayasa Sistem Industri, 8(2), 75-80. https://doi.org/10.26593/jrsi.v8i2.3 224.75-80

Supranto, J. (2000). Statistik: Teori \& Aplikasi (6th ed.). Erlangga.

Suprayitno, A. R., Sumardjo, S., Gani, D. S., \& Sugihen, B. G. (2015). Motivasi dan Partisipasi Petani dalam Pengelolaan Hutan Kemiri di Kabupaten Maros Provinsi Sulawesi Selatan. Jurnal Penyuluhan, 8(2). https://doi.org/10.25015/penyuluha n.v8i2.9883

Susilowati, S. H. (2019). Fenomena penuaan petani dan berkurangnya tenaga kerja muda serta implikasinya bagi kebijakan pembangunan pertanian.

Wahyuni, S. (2015). Integritas Kelembagaan Petani Gapoktan dan P3A. Iptek Tanaman Pangan, $5(1)$.

Zhang, X., Kuchinke, L., Woud, M. L., Velten, J., \& Margraf, J. (2017). Survey method matters: Online/offline questionnaires and face-to-face or telephone interviews differ. Computers in Human Behavior, 71, 172-180. 